\title{
Simplification of the procedure for testing common rail fuel injectors
}

The paper presents a simplified methodology for generating the characteristic curve of fuel doses for common rail injectors, which consists in limiting the number of measurements on the test bench and calculating missing data using predefined (array) functions of the Microsoft Excel spreadsheet. This allows checking the method of fuel delivery in a wide spectrum of predefined pressures and atomiser opening times, while reducing the arduousness and time-consumption of the active experiment phase. The proposed solution is particularly useful in problematic situations when standard manufacturer's tests, referred only to selected work points, make it impossible to clearly assess the technical condition of the injector.

Key words: common rail injector, fuel doses characteristic curve, simplification of test procedures

\section{Introduction}

All tests of fuel injection apparatus requiring the dismantling of its actuators from the engine belong to invasive methods [13]. The most reliable and precise way to diagnose fuel injectors are test-bench tests, which are performed on dedicated test benches [11]. They are universal bench devices equipped with single or multiple measuring chain systems. They can be compact in design or modular, enabling the installation of equipment compatible with the capabilities and the profile of operations of a given car workshop or service company. The benches have all the necessary adapters and connectors, both for fixing the fuel injector and connecting the hydraulic and electric lines. This allows not only for diagnostic tests, but also for thermochemical flushing, i.e. the process of internal cleaning under high pressure and at elevated detergent temperature [12].

Standard tests of the common rail fuel injector are performed in automatic cycles or, much less often, with manual settings. Usually they include several operating points for different pressures of the supplied fuel and atomiser opening (actuation) times, according to the manufacturer's recommendations [8]. Unfortunately, many years of workshop and laboratory practice indicates that such measurements may prove to be insufficient, primarily due to improper fuel dosing in other areas of engine operation. Detection of these irregularities is possible, but after preparing the full characteristics of the fuel doses. Despite the undoubted benefits, this function is rarely used, only in justified cases, which results from the arduousness and timeconsumption of the test phase. As a result, the process of checking a set from one engine becomes problematic and economically unjustified. Therefore, an own methodology was proposed, the idea of which is based on limiting the number of measurements to the necessary minimum and calculating the remaining data in the environment of a popular spreadsheet.

\section{Methods}

\subsection{Test object and test beds}

The test was carried out on the example of a Bosch CRI1 electromagnetic fuel injector (Fig. 1), which was dismantled from a Fiat 1.3 JTD 16V MultiJet diesel engine with an operating mileage of $158,000 \mathrm{~km}$.

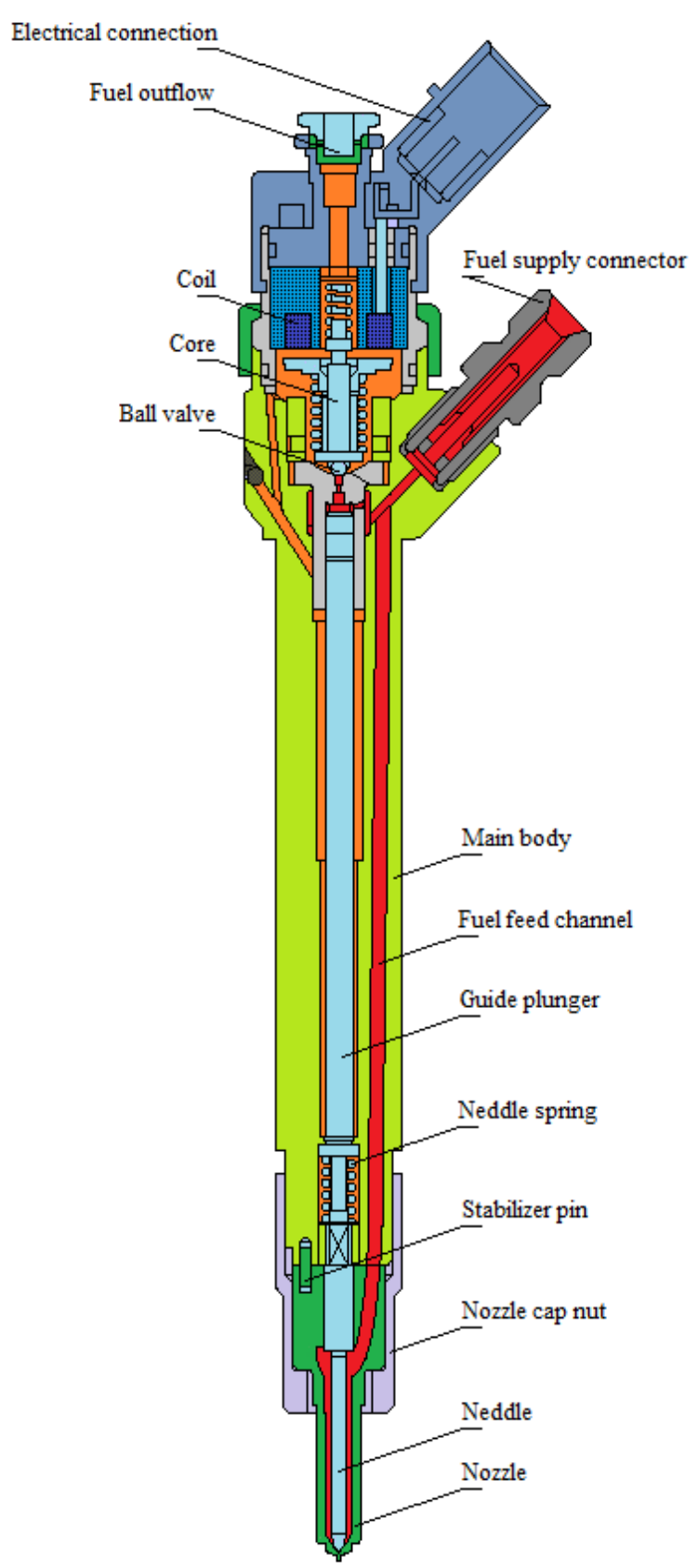

Fig. 1. CRI1 Bosch fuel injector design 
Fuel injectors of this type are commonly used in the combustion engines of passenger cars, working at maximum fuel injection pressures of up to $140 \mathrm{MPa}$ [16]. Because the manufacturer has made available the technology for their diagnostics, while offering a set of original spare parts, they can be regenerated to almost full extent [14].

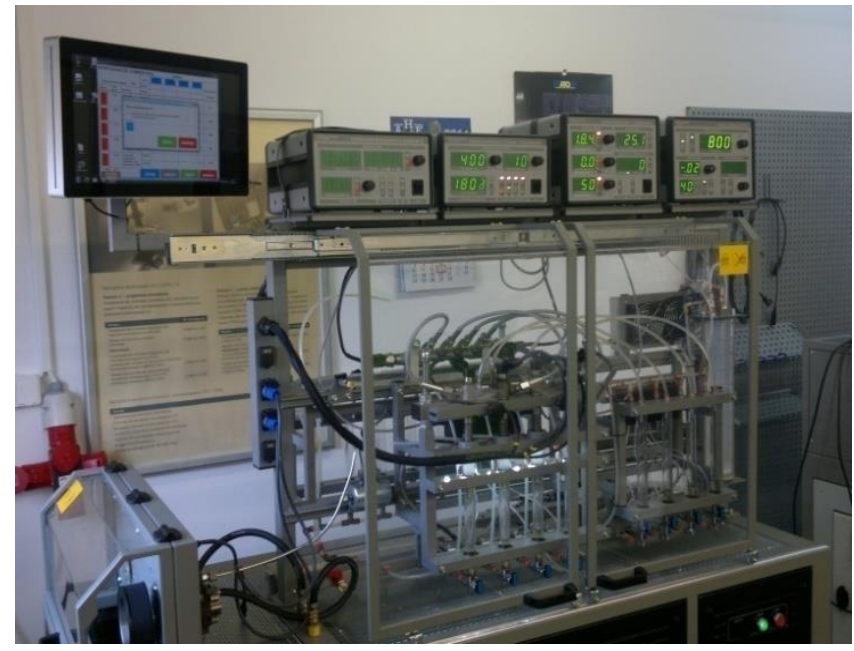

Fig. 2. Test bench STPiW-3 [17]

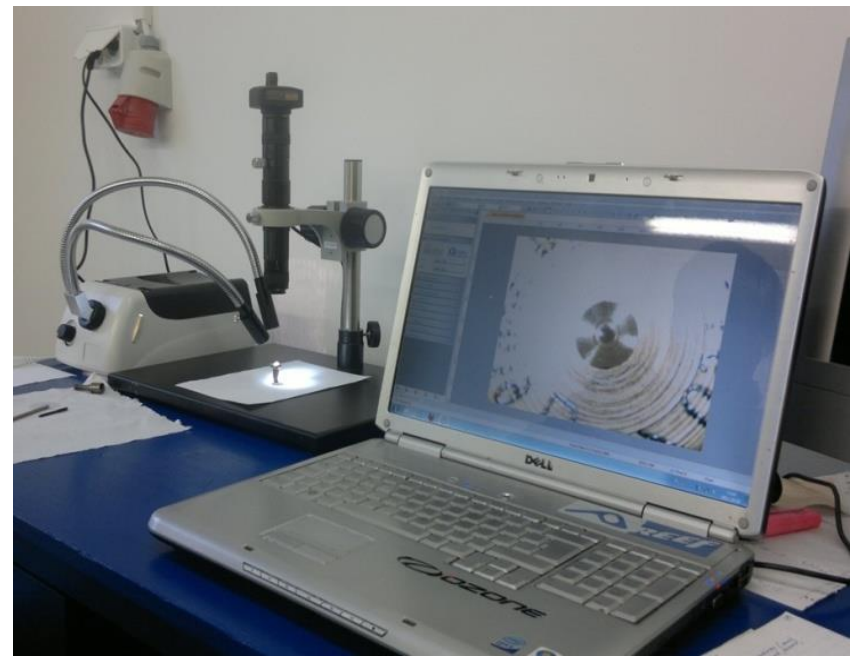

Fig. 3. Microscope Meiji FL150/70 [19]

The following systems and instrumentation were used in the repair process:

- STPiW-3 test bench (Fig. 2),

- 3-phase Bosch gear (CRR 120 pneumatic generator and CRR 220 electric generator, CRR 420 digital sensor, LAB/SM135 power supply, CRR 320 torque wrench),

- Meiji FL150/70 microscope (Fig. 3),

- MIC-40700 multimeter,

- ultrasonic baths (Carbon Tech Ultrasonic Bath S15/C2, Elmasonic S10H),

- vices and gear required for the disassembly and assembly phase.

In order to prepare a full characteristics of the fuel doses in a simplified way, measurements on the test bench were carried out at the predefined actuation times (main nodes) $t$ $[\mu \mathrm{s}]: 200,300,600,1200$. The obtained test results were entered into a Microsoft Excel spreadsheet, after which the missing data were estimated in indirect points.

\subsection{Predefined (array) functions}

For the calculation of fuel injector fuel doses $d$ that were not included in the experiment phase, predefined functions: LINEST and TREND, were used. The first of them allows you to fit a straight line to a set of points, but it can be successfully used to determine the coefficients in the multiple regression equation in the form of a polynomial. For this purpose, a column of t-values raised to the appropriate power is prepared for each word, or array operations are used, but the order of the exponents should be reversed by creating the following formula:

$$
\begin{gathered}
=\operatorname{SUM}\left(\text { LINEST } \left(\text { known_d`s; known_t`s }{ }^{\wedge}\{1 \backslash 2\} *\right.\right. \\
\left.\mathrm{t}^{\wedge}\{2 \backslash 1 \backslash 0\}\right)
\end{gathered}
$$

On the other hand, the TREND function is used directly for data interpolation (e.g. polynomial, rational), hence the following expression is used to calculate its value at any selected point of the discrete interval:

$$
\begin{gathered}
=\operatorname{SUM}\left(T R E N D\left(k n o w n \_d ` s ; k_{0} n n_{-} t^{`} \mathrm{~s}^{\wedge}\{1 \backslash 2\}\right) ;\right. \\
\left.\mathrm{t}^{\wedge}\{1 \backslash 2\}\right)
\end{gathered}
$$

In the next step, the addresses of the cells in which the results of the measurements were entered are substituted, i.e. the ranges of data known_t's and known_d's, as well as the value of the sought indirect argument $t$.

Formulas (1) and (2) can be used interchangeably because they offer the same quality of approximation [5]. In addition, when dividing a discrete area into two parts, low degree polynomials are used to create the so-called spline [6]. In this way, the risk of interference and oscillation (local extremes) that could occur with a single interpolation function [4] is eliminated.

\section{Analysis results and discussion}

\subsection{Preliminary tests}

Before starting the tests on the STPiW-3 test bench, the fuel injector was dismantled into its components, which were subjected to baths in ultrasonic baths and thoroughly dried.

During the microscopic examination, traces of initial frictional wear of the surface of plunger and barrel assemblies were found, which due to increased resistance limited the dynamics of the operation of the needle with the atomiser (Fig. 4). This negatively affects the fuel delivery process and uneven engine operation, in particular at idle or when setting low loads [7]. This type of defect is found very often and is detected even at low operational mileage [1]. In addition, valve seat deformation (Fig. 5) was observed, which leads to an overestimation of the volume of fuel going to the overflow. The occurrence of this malfunction results from various reasons, including the wrong ball travel [22]. However, this parameter was checked after the plunger and barrel assembly, guide piston and control valve assembly were replaced. Both in the mechanical AH (Ger. Ankerhub) and electric AHe (Ger. Ankerhub elektrisch) tests, the result was $0.051 \mathrm{~mm}$, which is within the manufacturer's acceptable range $(0.0030-0.060 \mathrm{~mm})$ [18]. Then 
the fuel injector was mounted on the STPiW-3 bench, where it successfully passed the approval procedures, including leakage and electrical tests.

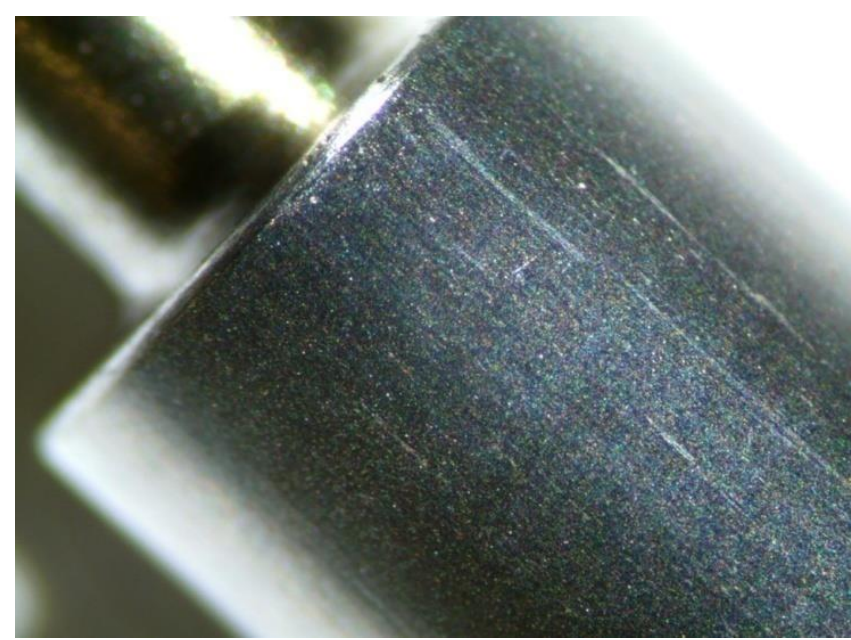

Fig. 4. Friction wear traces on the needle

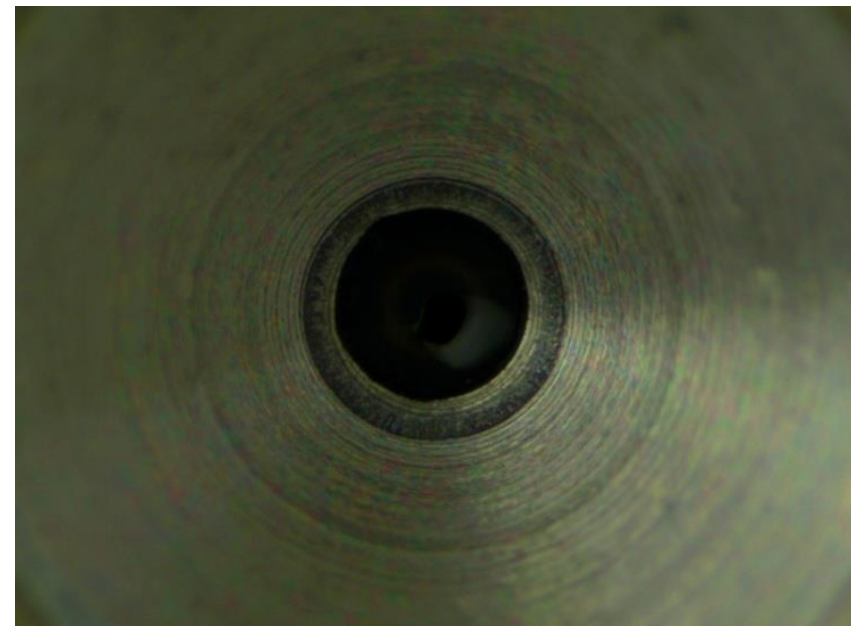

Fig. 5. Valve seat deformation

\subsection{Main tests}

Table 1 presents the results of measurements carried out on the test bench. The data obtained in the calculation process is also specified, the course of which is discussed on the example of selected fuel doses at fuel injection pressure $\mathrm{p}_{\text {inj }}=140 \mathrm{MPa}$.

The introduction of cell addresses in formulas (1) and (2) allowed to estimate the value of interpolation polynomial for the first indirect argument $\mathrm{t}=250 \mu \mathrm{s}$ :

$$
\begin{gathered}
7.6=\operatorname{SUM}\left(\operatorname { L I N E S T } \left(5.8: 36.6 ; 200: 600^{\wedge}\{1 \backslash 2\} *\right.\right. \\
\left.250^{\wedge}\{2 \backslash 1 \backslash 0\}\right)
\end{gathered}
$$

or

$$
\begin{gathered}
7.6=\operatorname{SUM}\left(\operatorname{TREND}\left(5.8: 36.6 ; 200: 600^{\wedge}\{1 \backslash 2\}\right) ;\right. \\
\left.250^{\wedge}\{1 \backslash 2\}\right)
\end{gathered}
$$

The fuel doses for the remaining atomiser opening times were calculated in a similar way. However, in the case of the second discrete interval, the formula was simplified due to the smaller number of measuring points. In this aspect, the predefined functions are much more flexible than the classic interpolation methods that are being implemented in a spreadsheet environment [9]. Hence for $t=1000 \mu$ s we obtained:

$$
\begin{gathered}
52.4=\operatorname{SUM}\left(\operatorname { L I N E S T } \left(36.6: 60.3 ; 600: 1200^{\wedge}\{1\} *\right.\right. \\
\left.1000^{\wedge}\{1 \backslash 0\}\right)
\end{gathered}
$$

or

$$
52.4=\operatorname{SUM}\left(\operatorname{TREND}\left(36.6: 60.3 ; 600: 1200^{\wedge}\{1\}\right) ;\right.
$$

$$
\left.1000^{\wedge}\{1\}\right)
$$

For obvious reasons, conducting two-way calculations is not required, but it does not pose any major difficulties and allows you to control the results obtained at every stage of this process. The correctness of the formulas can also be checked in another way, namely by substituting any selected root node. In this case, the value of the interpolating function must be equal to the measurement result at this point [3]. For example, for $\mathrm{t}=1200 \mu \mathrm{s}$, we obtained:

$$
\begin{gathered}
\mathbf{6 0 . 3}=\operatorname{SUM}\left(\operatorname { L I N E S T } \left(36.6: \mathbf{6 0 . 3} ; 600: 1200^{\wedge}\{1\} *\right.\right. \\
\left.1200^{\wedge}\{1 \backslash 0\}\right)
\end{gathered}
$$

or

$$
\begin{gathered}
\mathbf{6 0 . 3}=\operatorname{SUM}\left(\operatorname{TREND}\left(36.6: \mathbf{6 0 . 3} ; 600: 1200^{\wedge}\{1\}\right) ;\right. \\
\left.1200^{\wedge}\{1\}\right)
\end{gathered}
$$

Figure 6 shows the characteristic curve of fuel doses for the tested injector $d=f(t)$, which were generated based on all results. By contrast, the measured points are marked in colour, and the calculated points are left without any fill.

The shape and course of individual curves should be assessed positively because they do not overlap or intersect the entire working area in question [20]. This indicates that there are no irregularities in the fuel delivery process [2]. In addition, the implementation of pre-defined functions simplified the active experiment phase and enabled the estimation of correct fuel doses values at any atomiser opening time. For example, according to Bosch diagnostic coordinates, the pilot dose VE (Ger. Voreinspritzung) and idling LL (Ger. Leerlauf) should be within $0.3-4.1 \mathrm{~mm}^{3} / \mathrm{inj}$ at $\mathrm{t}=260 \mu \mathrm{s}, \mathrm{p}_{\text {inj }}=80 \mathrm{MPa}$ and $0.3-3.9 \mathrm{~mm}^{3} /$ inj at $\mathrm{t}=420 \mu \mathrm{s}$, $p_{\text {inj }}=30 \mathrm{MPa}$ [15]. In both cases these requirements were met because the values $d_{V E}=3.9 \mathrm{~mm}^{3} /$ inj and $d_{L L}=2.3$ $\mathrm{mm}^{3}$ /inj were obtained.

It is worth emphasising that the detection of irregularities in this area would require the dismantling of the fuel injector again and fuel delivery correction. In addition to adjusting the ball travel, the air gap between the control unit disc and the coil body, the needle travel, and the valve spring force should be checked. The steps included in respective stages regulation match the standard Bosch procedures.

\section{Conclusions}

Despite the variety of diagnostic methods, more and more often directed at conducting measurements under the conditions of real operation on the engine, the basis of modern research laboratories are test benches. They enable a comprehensive assessment of common rail fuel injectors, 
Table 1. Results of test-bench test and calculations for CRI1 Bosch injector

\begin{tabular}{|c|c|c|c|c|c|c|c|c|}
\hline \multirow{2}{*}{ Lp. } & \multirow{2}{*}{$\begin{array}{l}\text { Injection pressure, } \\
\text { Actuation } \\
\text { time, } \\
\mathrm{t}[\mu \mathrm{s}]\end{array}$} & \multicolumn{7}{|c|}{$\begin{array}{c}\text { Fuel dose } \\
\mathrm{d}\left[\mathrm{mm}^{3} / \text { inj.] }\right.\end{array}$} \\
\hline & & 140 & 120 & 100 & 80 & 60 & 40 & 30 \\
\hline 1 & 200 & 5,8 & 5,2 & 4,5 & 3,1 & 1,7 & 0,2 & 0,1 \\
\hline $2 *$ & 250 & 7,6 & 6,2 & 5,1 & 3,8 & 2,4 & 0,8 & 0,4 \\
\hline 3 & 300 & 9,9 & 7,8 & 6,4 & 4,9 & 3,5 & 1,5 & 0,8 \\
\hline $4 *$ & 400 & 16,4 & 13,1 & 11,0 & 8,7 & 6,6 & 3,5 & 2,0 \\
\hline 5 & 600 & 36,6 & 32,0 & 28,3 & 22,2 & 16,8 & 9,7 & 5,7 \\
\hline $6^{*}$ & 800 & 44,5 & 40,2 & 36,1 & 29,7 & 24,1 & 16,2 & 11,9 \\
\hline $7 *$ & 1000 & 52,4 & 48,5 & 44,9 & 37,2 & 31,3 & 22,6 & 18,2 \\
\hline 8 & 1200 & 60,3 & 56,7 & 53,2 & 44,7 & 38,6 & 29,1 & 24,4 \\
\hline
\end{tabular}

$\mathrm{d}\left[\mathrm{mm}^{3} /\right.$ injection $]$

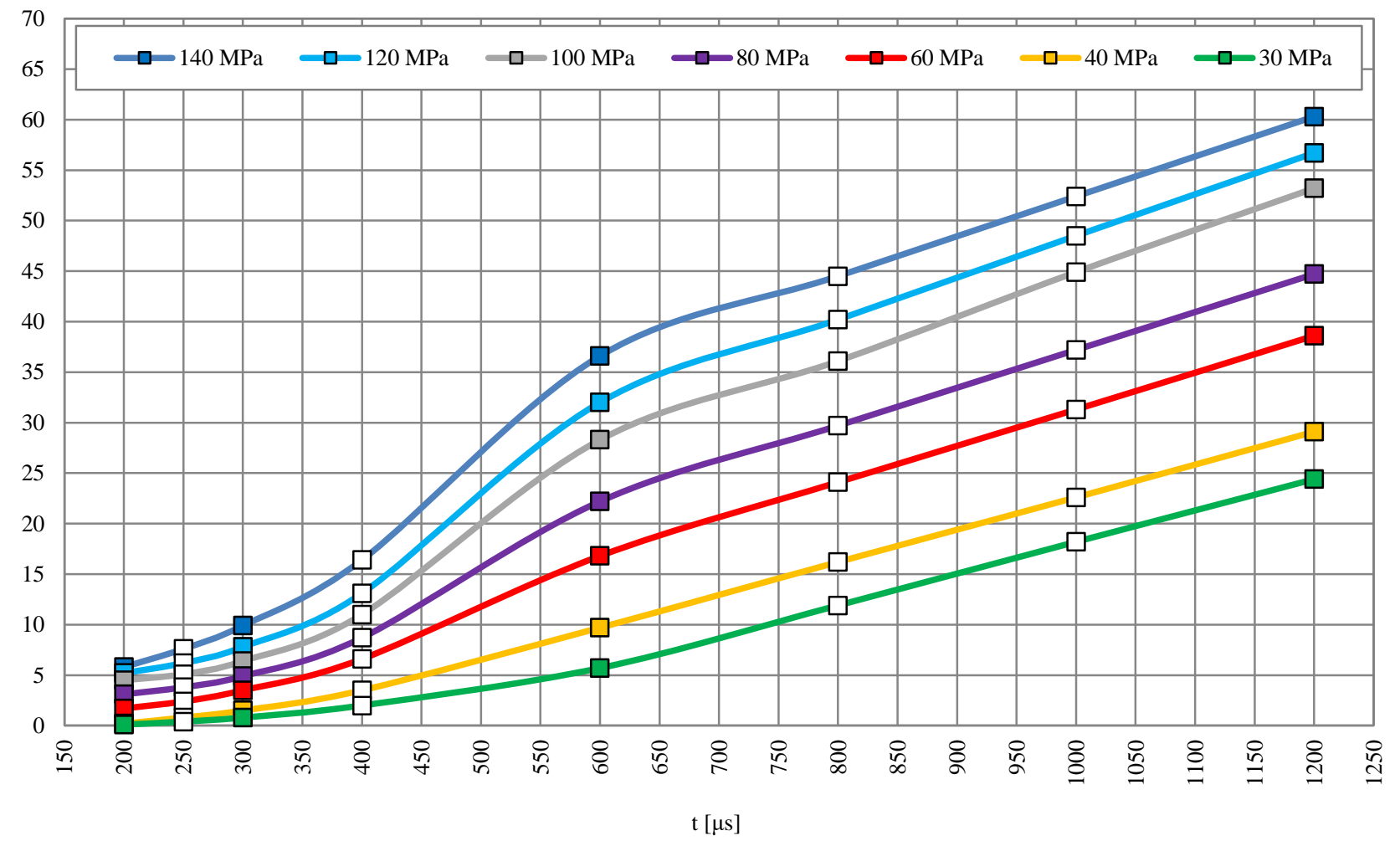

Fig. 6. Fuel doses characteristic curve for the injector tested

indicating at the same time areas of their incorrect operation [10]. Therefore, improving test procedures seems to be the most reasonable, taking into account technical criteria (accuracy, repeatability, durability), as well as economic ones (cost, efficiency, labour consumption). The proposed methodology can be useful to meet them, as it has been used in laboratory and workshop practice.

One of the most important advantages of a spreadsheet is the ability to automatically recalculate all formulas after changing the input variables [21]. In this way, a quick pre- view of their effect on the final results is obtained, which, with a wide set of implemented predefined functions, gives a very useful tool for processing and presenting data. In the analysed case, two of them were used, simplifying the active experiment phase by eliminating 28 measuring points. In addition, calculations in the digital environment did not require the presentation of the final form (formulas) of interpolation polynomials, but only an estimate of their values for each indirect argument.

\section{Nomenclature}

AH mechanical measurement of ball travel (Ger. Ankerhub)

AHe electrical measurement of ball travel (Ger. Ankerhub elektrisch)

d fuel dose

CRI1 first generation common rail injector made by Bosch

JTD multiJet Turbo Diesel

LINEST predefined linear regression function 
LL idling dose (Ger. Leerlauf)

$\mathrm{p}_{\mathrm{inj}} \quad$ injection pressure

$\mathrm{t} \quad$ actuation (atomiser opening) time
TREND predefined interpolating function

VE pilot dose (Ger. Voreinspritzung)

\section{Bibliography}

[1] ABRAMEK, K.F., STOECK, T., OSIPOWICZ T. Statistical Evaluation of the corrosive wear of fuel injector elements used in common rail systems. Strojniški vestnik - Journal of Mechanical Engineering. 2015, 61(2), 91-98. https://doi.org/10.5545/sv-jme.2014.1687

[2] BUSZ, W., WALASZYK, A. Optimize the testing process common rail fuel injectors. Combustion Engines. 2015, 162(3), 978-981.

[3] CHENEY, W., KINCAID, D., Numerical Mathematics and Computing (7th Ed.). Books/Cole Publishing Company. 2012, Pacific Grove.

[4] GAUTSCHI, W. Interpolation before and after Lagrange. Rendiconti del Seminario Matematico Università e Politecnico di Torino. 2012, 70(4), 347-368.

[5] GONET, M. Excel w obliczeniach naukowych i technicznych. Wydawnictwo Helion. 2010, Gliwice.

[6] HOFFMAN, J.D., Numerical methods for engineers and scientists. Marcel Dekker, Inc. 2001, New York-Basel.

[7] JUŚCIŃSKI, S., PIEKARSKI, W., CHOMIK, Z. Analysis of injection systems types used in agricultural machines. $\mathrm{Ag}$ ricultural Engineering. 2017, 21(4), 37-46. https://doi.org/10.1515/agriceng-2017-0034

[8] KARPIUK, W., BOR, W., SMOLEC, R. Possibilities of analysis of condition and repair of common-rail system injectors. Journal of KONES Powertrain and Transport. 2018, 23(4), 209-216.

https://doi.org/10.5604/12314005.1217208

[9] KARRIS, S.T. Numerical analysis using MATLAB® and Excel ${ }^{\circledR}$ (3th Ed.). Orchard Publications. 2007, Berkeley.

[10] KLUCZYK, M., GRZĄDZIELA, A. Marine diesel engine common rail injectors monitoring with vibration parameters. Diagnostyka. 2019, 19(3), 37-44. https://doi.org/10.29354/diag/109793

[11] KLUCZYK, M., GRZĄDZIELA, A. Vibration diagnostics of common rail injectors. Journal of Marine Engineering \& Technology. 2017, 16(4), 177-184. https://doi.org/10.1080/20464177.2017.1387088

[12] KNEBA, Z., STRASZAK, P., JAKÓBCZYK, K. The effectiveness of fault detection in common rail injectors examina-

Tomasz Stoeck, DEng. - Faculty of Mechanical Engineering and Mechatronics, West Pomeranian University of Technology in Szczecin.

e-mail: tstoeck@wp.pl tion methods. Combustion Engines. 2017, 170(3), 49-56. https://doi.org/10.19206/CE-2017-308

[13] OLSZOWSKI, S., CHOJNACKI, T., OLSZOWSKI, T. Nieprawidłowa praca wtryskiwaczy common rail pomimo pozytywnego wyniku badania. Autobusy - Technika, Eksploatacja, Systemy Transportowe. 2017, 6, 1003-1007.

[14] OSIPOWICZ, T., ABRAMEK, K.F. Diagnosing methods common rail fuel injectors. Combustion Engines. 2017, 168(1), 56-61. https://doi.org/10.19206/CE-2017-109

[15] OSIPOWICZ, T., KOWALEK, S. Evaluation of Modern Diesel Engine Fuel Injectors. TEKA - Commission of Motorization and Energetics in Agriculture. 2014, 14(3), 83-87.

[16] REIF, K. (Ed.). Automotive Mechatronics. Bosch Professional Automotive Information. Springer Fach-medien. 2015. https://doi.org/10.1007/978-3-658-03975-2

[17] STOECK, T. Application of the experimental design technique in fuel dose adjustment of common rail injector. Combustion Engines. 2019, 179(4), 210-215. https://doi.org/10.19206/CE-2019-435

[18] STOECK, T., OSIPOWICZ, T. Analiza uszkodzeń wtryskiwaczy Common Rail firmy Bosch stosowanych w silnikach wysokoprężnych pojazdów użytkowych. Logistyka. 2013, 6, 723-727.

[19] STOECK, T., OSIPOWICZ, T. Przyczyny tworzenia się osadów we wtryskiwaczach Common Rail. Autobusy Technika, Eksploatacja, Systemy Transportowe. 2016, 8, 139-141.

[20] VASILIU, D., VASILIU, G.C., RĂDULESCU, A. et al Predicting the dynamic performance of the fuel injectors by numerical simulation. Scientific Bulletin. Series C: Electrical engineering and Computer Science. 2018, 78(4), 173188. University Politehnica of Bucharest.

[21] WALKENBACH, J. Excel 2013 Formulas. John Wiley \& Sons, Inc. 2013, Hoboken, New Jersey.

[22] YORDANOV, N., HADJIEW, K., STANKOW, E. Experimental simulation of common rail electromagnetic injectors wearing. Machines, Technologies, Materials. 2018, 12(4), 208-211. 